\title{
IPTEKS BAGI MASYARAKAT KELOMPOK TANI PRODUKSI PESTISIDA NABATI KARANGMELOK, KECAMATAN TAMANAN, BONDOWOSO
}

\author{
Hariyono Rakhmad1) dan Triono Bambang Irawan'2) \\ 1)Jurusan Teknologi Informasi, 2) Jurusan Produksi Pertanian \\ Politeknik Negeri Jember
}

\begin{abstract}
ABSTRAK
IbM Produksi Pestisida Nabati ini dilaksanakan di Kelompok Tani Karya Tani I dan Kelompok Tani Karya Tani II Desa Karang Melok Kecamatan Tamanan Kabupaten Bondowoso. Solusi yang ditawarkan dalam Program IbM ini yaitu: (i) merancang Prosedur Operasi Standar pembuatan pestisida nabati yang berasal dari ekstrak akar, daun dan batang tanaman; (ii) membuat modul Pengendalian Hama dan Penyakit Terpadu; (iii) Buku Kerja Praktek Petani: beberapa macam pestisida nabati untuk OPT; (iv) pelatihan produksi pestisida nabati; (v) aplikasi hasil produksi pestisida nabati ke tanaman produksi di areal sawah milik kelompok tani; (vi) membuat desain produk pestisida nabati yang diproduksi oleh kelompok tani; (vii) evaluasi dan pendampingan hasil aplikasi pestisida nabati untuk tanaman padi.

Target luaran dari kegiatan Program IbM Kelompok Tani Produksi Pestisida Nabati Desa Karangmelok, Kecamatan Tamanan, Bondowoso adalah: (i) Modul Pengendalian Hama Terpadu sebagai Sistem Perlindungan Tanaman Padi, Palawija dan Sayuran; (ii) Buku Kegiatan Praktek Petani: Pestisida Nabati Wereng Coklat, Xanthomonas camprestis, Penyakit Tungro, Penggerek Batang Padi (Sundep), Lalat Bibit dan Bulai; (iii) Produk Pestisida Nabati untuk Padi, Palawija dan Sayuran, kapasitas 5 liter/hari; (iv) Unit Produksi Pestisida Nabati di masing-masing kelompok tani Karya Tani I dan Karya Tani II.
\end{abstract}

\section{PENDAHULUAN}

Pada tahun 2013, luas lahan untuk produksi padi organik baru mencapai 35 ha, tetapi produksi padi organik yang dikelola oleh petani mengalami peningkatan pesat. Rata-rata produktivitas padi saat ini berkisar 5.7 ton/ha. Sedangkan, hasil ubinan di beberapa tempat yang sudah menggunakan pupuk organik dengan varietas hibrida mencapai rata-rata 10 ton/ ha. Sehingga petani ada peluang untuk meningkatkan kualitas dan kuantitas produktivitas padinya sekitar 4,3 ton atau sekitar 75 persen per hektarnya. Bahkan di beberapa wilayah tertentu, memiliki potensi untuk dijadikan cluster pertanian organik murni.

Secara umum, di areal lahan sawah di kabupaten Bondowoso menunjukkan serangan hama penyakit tanaman pada padi yang terus menerus meningkat karena umumnya petani selalu menggunakan pestisida kimia yang dapat mengakibatkan: (i) munculnya biotype hama yang baru dan kebal; (ii) matinya serangga-serangga yang membantu petani; (iii) pencemaran lingkungan dan menimbulkan keracunan pestisida; (iv) harga pestisida kimia semakin mahal sehingga sangat berdampak negatif dalam rantai produksi tanaman.

Cara yang paling baik untuk mencegah pencemaran pestisida kimia adalah dengan tidak menggunakan pestisida kimia sebagai pemberantasan hama. Mengingat akibat sampingan yang terlalu berat, atau bahkan menyebabkan rusaknya lingkungan, dan merosotnya hasil panen, penggunaan pestisida kimia mulai dikurangi. Pengendalian hama dengan pestisida kimia harus dilakukan sebijaksana mungkin, bahkan dapat ditiadakan, dalam rangka mewujudkan pembangunan pertanian yang berwawasan lingkungan.

Penggunaan pestisida nabati merupakan salah satu solusi terbaik untuk mengatasi dampak negatif dari penggunaan pestisida kimia. Pestisida nabati adalah pestisida yang bahan aktifnya berasal dari tumbuhan atau bagian tumbuhan seperti akar, daun, batang atau buah. Bahan-bahan ini diolah menjadi berbagai bentuk, antara lain bahan mentah berbentuk tepung, ekstrak atau resin yang merupakan hasil pengambilan cairan metabolit sekunder dari bagian tumbuhan atau bagian tumbuhan dibakar untuk diambil abunya dan digunakan sebagai pestisida.

Khusus di Kecamatan Tamanan secara administrasi berpenduduk sebanyak: 36.287 orang terdiri dari laki-laki: 17.828 orang dan perempuan: 18.459 orang. Kecamatan Tamanan membawahi:

- Jumlah Desa : 9 desa (Kalianyar,

Karangmelok, Kemirian,

Mengen,

Tamanan,Wonosuko).

- Jumlah Dusun : 38 dusun 
- Jumlah Ka. Desa : 9 orang

- Jumlah perangkat : :93 orang

Luas tanah sawah di Kecamatan Tamanan yaitu: $1.256 \mathrm{Ha}$, tanah tegal/ladang: $1.181 \mathrm{Ha}$, tanah pekarangan: $442.7 \mathrm{Ha}$, tanah lain-lain: 93.8 Ha. Umumnya tanaman yang ditanam oleh petani antara lain: padi, palawija (kedelai, jagung, kacang tanah, kacang hijau dan lain-lain) dan berbagai macam sayuran (cabai, pack choi, sawi putih, kangkung darat, dan lain-lain).

Aplikasi dan Produksi Pestisida Nabati akan dilaksanakan di Kelompok Tani Karya Tani II Desa Karang Melok dan Kelompok Tani Karya Tani I Desa Karang Melok Kecamatan Tamanan yang menjadi mitra IbM.

Pemerintah Kabupaten Bondowoso, melalui SKPD Dinas Tanaman Pangan dan Hortikulura telah membuat program Sekolah Lapang Pengendalian Tanaman Terpadu (SL-PTT) sejak 2008, tetapi tidak semua kelompok tani memahami secara teknis pembuatannya pestisida nabati terutama pestisida nabati yang dibutuhkan untuk pengendalian hama-hama tertentu.

\section{Permasalahan Mitra}

Dari analisis situasi, dapat diuraikan permasalahan mitra program IbM ini yang muncul dan menjadi prioritas sebagai berikut:

1. Munculnya berbagai macam hama dan penyakit yang menyerang areal tanaman padi dan palawija, antara lain: hama penggerek padi kuning, hama ganjur, penyakit tungro, hama sundep dan hama weluk.

2. Populasi hama yang semakin meningkat terutama hama wereng coklat yang menyerang tanaman padi di areal sawah.

3. Terjadinya ledakan hama secara tiba-tiba yang menyerang areal pertanaman di kedua kelompok tani tersebut, disebabkan musuh alami organisasi pengganggu tanaman mati akibat pemakaian pestidida kimia yang terus menerus.

4. Jumlah dosis pestisida kimia yang digunakan terus meningkat.

5. Makin banyaknya macam pestisida kimia (insektisida, fungisida, molusida) yang diaplikasikan ke pertanaman.

6. Harga pestisida kimia yang terus meningkat, menyebabkan biaya produksi usaha tani meningkat tajam.

7. Kurangnya informasi pembuatan dan aplikasi pestisida nabati, dengan bahan yang dapat dimanfaatkan di sekitar lahan petani.
Untuk itu disepakati antara Tim IbM POLIJE dengan ke dua kelompok tani di atas untuk memproduksi dan mengaplikasikan pestisida nabati ke lahan pertanian ke dua kelompok tani tersebut.

\section{TARGET DAN LUARAN}

\section{Target}

Umumnya pola tanam yang berlaku pada kedua kelompok tani di atas adalah: padi + padi + palawija dalam satu tahun musim tanam. Konsentrasi pestisida nabati adalah 700 ml / 13.3 liter air (1 tangki). Dibutuhkan 20 tangki setiap aplikasi pestisida nabati untuk $1 \mathrm{Ha}$, maka dibutuhkan 14 liter pestisida nabati / aplikasi. Umumnya waktu pemeliharaan tanaman padi 70 hari, dengan 2 kali aplikasi setiap Minggu maka total kebutuhan pestisida nabati sebanyak 280 liter / Ha. Dengan total luas lahan $67 \mathrm{Ha}$, maka diperkirakan kebutuhan pestidida nabati sebanyak 56.280 liter selama setahun (3 kali musim tanam).

Target dari kegiatan Program IbM Kelompok Tani Produksi Pestisida Nabati Desa Karangmelok, Kecamatan Tamanan, Bondowoso adalah:

1. Terbentuknya Unit Produksi Pestisida Nabati di kelompok tani Karya Tani I dan Karya Tani II.

2. Terwujudnya produk pestisida nabati yang dibuat oleh kelompok tani Karya Tani I dan Karya Tani II;

3. Mempercepat terwujudnya pemakaian pestisida nabati oleh kelompok tani, sehingga menurunkan pemakaian pestisida kimia;

4. Mempercepat difusi dan pemanfaatan iptek pembuatan pestisida nabati untuk tanaman padi, palawija dan sayuran kepada anggota kelompok tani yang tergabung dalam kelompok Tani Karya Tani I dan Kelompok Tani Karya Tani II;

5. Mengaplikasi hasil produksi pestisida nabati ke tanaman produksi di areal sawah milik kelompok tani;

6. Menghasilkan desain produk pestisida nabati yang diproduksi oleh kelompok tani.

\section{Luaran dan Spesifikasinya}

Luaran dari kegiatan Program IbM Kelompok Tani Produksi Pestisida Nabati Desa Karangmelok, Kecamatan Tamanan, Bondowoso adalah:

1. Terbentuknya 1 unit produksi Pestisida Nabati di kelompok tani Karya Tani I dan Karya Tani II.

2. Terwujudnya produksi pestisida nabati sebanyak 29.400 liter dalam 3 kali musim 
tanam selama 1 tahun di kelompok tani Karya Tani I.

3. Terwujudnya produksi pestisida nabati sebanyak 26.880 liter dalam 3 kali musim tanam selama 1 tahun di kelompok tani Karya Tani II.

4. Modul Pengendalian Hama Terpadu sebagai Panduan Sistem Perlindungan Tanaman Padi, Palawija dan Sayuran.

5. Buku Kegiatan Praktek Petani : Pestisida Nabati Wereng Coklat, Pestisida Nabati Xanthomonas camprestis, Pestisida Nabati penyakit tungro, Pestisida Nabati Penggerek Batang Padi (Sundep), Pestisida Nabati Lalat Bibit, Pestisida Nabati Bulai.

\section{METODE PELAKSANAAN}

\subsection{Pelaksanaan Kegiatan}

Dari sekian banyaknya permasalahan mitra Program IbM yang telah diuraikan sebelumnya, maka metode pendekatan yang yang ditawarkan untuk mengurangi pemakaian pestisida kimia sekaligus menerapkan pengendalian hama terpadu (PHT) maka telah disepakati bersama antara tim Pelaksana Program IbM Politeknik Negeri Jember dengan Pengurus Kelompok Tani Karya Tani I dan Kelompok Tani Karya Tani II, adalah sebagai berikut.

1. Membentuk unit-unit produksi Pestisida Nabati di kelompok tani Karya Tani I dan II melalui pertemuan bersama antara tim pelaksana dengan mitra.

2. Membuat modul Pengendalian Hama dan Penyakit Terpadu dan Merancang Prosedur Operasi Standar pembuatan pestisida nabati yang berasal dari ekstrak akar, daun dan batang tanaman

3. Menyusun Buku Kerja Praktek Petani : beberapa macam pestisida nabati untuk OPT

4. Pelatihan Produksi pestisida nabati dan mengaplikasi hasil produksi pestisida nabati ke tanaman produksi di areal sawah milik kelompok tani

5. Evaluasi dan pendampingan hasil aplikasi pestisida nabati untuk tanaman padi dan membuat laporan.

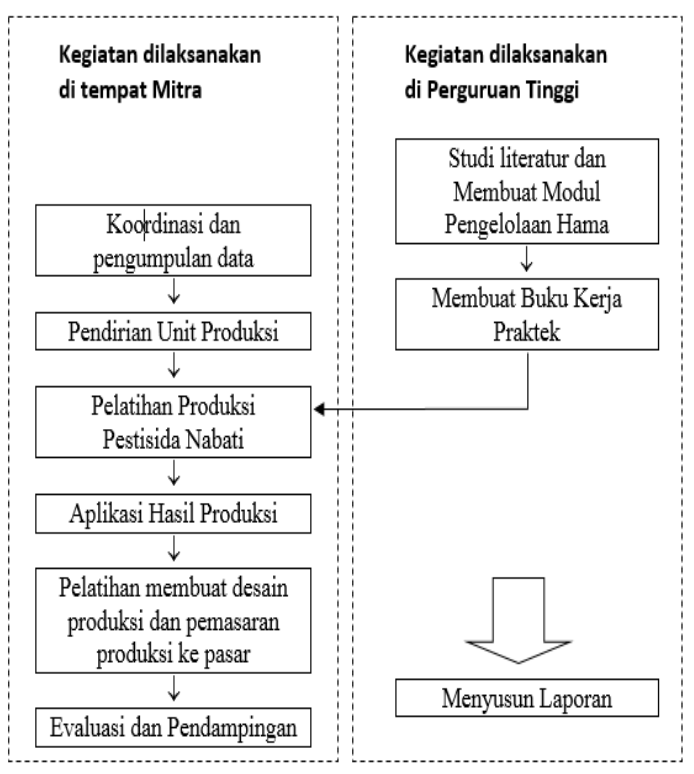

Gambar 1. Tahapan Kegiatan

\subsection{Pelaksanaan Program dan Peran Mitra}

1. Melakukan koordinasi dengan mitra untuk mendirikan tempat produksi pestisida nabati (diskusi perancangan dan keselamatan kerja, tata letak, peralatan, penyimpanan bahan baku, penyimpanan hasil produk).

2. Peserta dari mitra mengikuti dengan seksama pelatihan berupa praktek produksi pestisida nabati yang dilaksanakan 4 kali pertemuan, dengan target peserta total sebanyak 20 orang dari kedua mitra IbM.

3. Kemudian peserta atau mitra pengabdian ini mengaplikasikan hasil produksi pestisida nabati ke tanaman produksi di areal sawah milik kelompok tani untuk melihat hasilnya dan melaporkannya kepada tim pelaksana IbM.

4. Tim pelaksana pengabdian melalui program IbM ini dilanjutkan dengan pembuatan Modul Pengendalian Hama dan Penyakit Terpadu dalam bentuk print out yang akan dibagikan saat pelatihan.

5. Tim pelaksana melakukan pembuatan Buku Kerja Praktek Petani (BKPP) yaitu beberapa macam pestisida nabati untuk OPT untuk selanjutnya peran mitra IbM adalah melakukan isian dari form yang terdapat pada BKPP tersebut. Dalam kegiatan pelatihan ini peserta melakukan pengisian data secara manual. 


\section{KELAYAKAN SUMBERDAYA PERGURUAN TINGGI}

\section{Sumberdaya Manusia}

Bidang ilmu anggota tim kegiatan ini adalah pengelolaan tanah dan air, yang juga pengampu mata kuliah Pengelolaan Pertanian Organik di Jurusan Produksi Pertanian Politeknik Negeri Jember. Dalam Pengelolaan Pertanian Organik, penerapan pestisida nabati merupakan salah satu rantai produksi produk pertanian organik.

Ketua tim kegiatan ini memiliki keahlian di bidang teknik informatika yang sesuai dengan kegiatan dalam desain produk, advertising dan pemasaran produk yang mendukung pelaksanaan kegiatan program IbM ini.

Tabel 1. Pelaksana Kegiatan

\begin{tabular}{|c|c|c|c|c|}
\hline No & Nama & Kedudukan & Kepakaran & $\begin{array}{l}\text { PPM } 1 \text { tahun } \\
\text { terakhir }\end{array}$ \\
\hline 1 & $\begin{array}{l}\text { Hariyono } \\
\text { Rakhmad, S.Pd, } \\
\text { M.Kom }\end{array}$ & $\begin{array}{l}\text { Ketua } \\
\text { Pelaksana }\end{array}$ & $\begin{array}{l}\text { Desain produk } \\
\text { Multimedia dan } \\
\text { Website, e- } \\
\text { commerce }\end{array}$ & $\begin{array}{l}\text { Pengembangan } \\
\text { Aplikasi Komputer } \\
\text { Isi Pulsa Untuk Bisnis } \\
\text { Pulsa "Rumah Pulsa" } \\
\text { di PrajekanLor } \\
\text { Bondowoso }\end{array}$ \\
\hline 2 & $\begin{array}{l}\text { Ir. Triono } \\
\text { Bambang Irawan, } \\
\text { MP }\end{array}$ & Anggota & $\begin{array}{l}\text { Pengelolaan } \\
\text { Tanah dan Air }\end{array}$ & $\begin{array}{l}\text { Penerapan Teknologi } \\
\text { Pupuk Organik Granul } \\
\text { Kapasitas } 5 \text { Ton / Hari } \\
\text { Berbasis Sumberdaya } \\
\text { Lokal }\end{array}$ \\
\hline
\end{tabular}

Keterlibatan mahasiswa dalam program IbM ini adalah membantu melaksanakan analisis dan identifikasi lapangan, pembuatan modul Pengelolaan Hama Terpadu (PHT) Pestisida Nabati dan menyiapkan fasilitas untuk pelatihan produksi pestisida nabati. Di samping itu membantu melaksanakan sosialisasi aplikasi pestisida nabati dan pendampingan tim Program IbM yang diikuti oleh para anggota kelompok tani di Desa Karang Melok, Kecamatan Tamanan, Bondowoso.

\section{HASIL YANG DICAPAI}

\section{Melakukan koordinasi dengan Mitra}

Kegiatan awal dari pelaksanaan IbM ini adalah melakukan koordinasi dengan mitra. Kegiatan ini bertujuan untuk mendata beberapa peserta yang dapat mengikuti pelatihan ini, serta membahas tempat dan waktu yang akan digunakan bersama. Sekaligus memetakan wilayah mana saja di kedua desa tersebut yang diprioritaskan untuk dibantu pemasangan lampu penerangan skala rumah tangga.

Membentuk unit-unit produksi Pestisida Nabati di kelompok tani Karya Tani I dan II
Unit-unit produksi Pestisida Nabati melalui pertemuan bersama antara tim pelaksana dengan mitra telah terbentuk. Tujuan dibentuknya unit ini adalah untuk:

1. Mempermudah koordinasi pelaksanaan aplikasi pestisida nabati di lahan kelompok tani.

2. Mempercepat terwujudnya pemakaian pestisida nabati oleh kelompok tani, sehingga menurunkan pemakaian pestisida kimia;

3. Mempercepat difusi dan pemanfaatan iptek pembuatan pestisida nabati untuk tanaman padi, palawija dan sayuran kepada anggota kelompok tani yang tergabung dalam kelompok Tani Karya Tani I dan Kelompok Tani Karya Tani II

\section{Membuat modul Pengendalian Hama dan Penyakit Terpadu}

Modul Pengendalian Hama dan Penyakit Terpadu telah dibuat dan diberikan kepada kelompok tani melalui ketua kelompok tani. Modul ini terdiri dari pengendalian hama dan penyakit pada padi, jagung, melon, cabai merah.

\section{Menyusun Buku Kerja Praktek Petani beberapa macam pestisida nabati untuk OPT}

Buku Kerja Praktek Petani telah disusun dalam bentuk buku BKPP yang merupakan prosedur:

- Pembuatan Pestisida Nabati Wereng cokelat

- Pembuatan Pestisida Nabati Xanthomonas campestris

- Pembuatan Pestisida Nabati Untuk Tungro

- Pembuatan Pestisida Nabati Penggerek Batang Padi

\section{Pelatihan Produksi Pestisida Nabati}

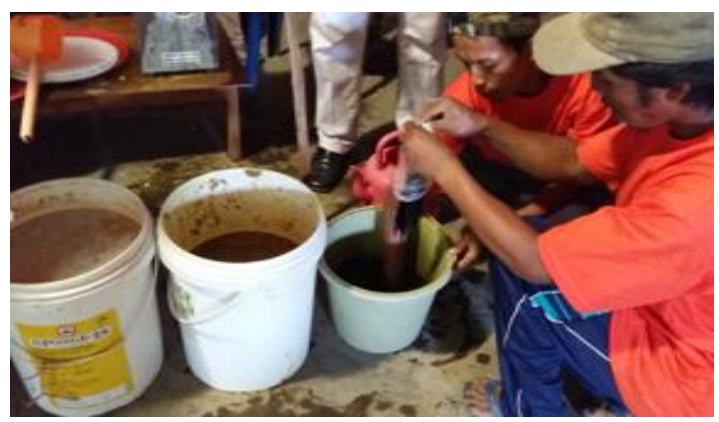

Gambar 2. Proses Pembuatan Pestisida

Pelatihan produksi pestisida nabati telah dilakukan sebanyak 4 kali pertemuan yang diikuti oleh peserta sebanyak 20 petani. Jumlah 
pertemuan lebih singkat karena petani sudah dapat mengikuti pelatihan dengan baik.

\section{KESIMPULAN DAN SARAN}

\section{Kesimpulan}

Hasil kegiatan yang dapat dilaporkan pada laporan kemajuan ini adalah bahwa beberapa tahapan dalam menyelesaikan agenda kegiatan dapat dilaksanakan dengan baik. Untuk menghasilkan tujuan yang maksimal perlu dilakukan monitoring dan evaluasi baik langsung maupun tidak langsung pada mitra kegiatan pelatihan khususnya terhadap peserta pelatihan. Sehingga diharapkan para petani peserta pelatihan dapat lebih mahir dan handal dalam membuat pestisida nabati ini dan kemudian dapat secara maksimal teraplikasikan kepada tanaman mereka yang terserang hama penyakit. Selanjutnya tahapan akhir yang akan diselesaikan adalah mengimplementasikan produksi ke tanaman petani pertanian.

\section{Saran}

Keterbatasan para petani adalah pada pendanaan. Maka semua kegiatan ini agar dapat terlaksana dengan baik dan lancar nantinya, sebaiknya diberikan wawasan akses pendanaan tambahan seperti bentuk-bentuk kegiatan pinjaman ventura agar semangat bisnis para petani dapat ditimbulkan .

\section{DAFTAR PUSTAKA}

Fajar Lestari, 2012. Pestisida Nabati Sebagai Alternatif Pengganti Pestisida Kimia Sintetik. Balai Penelitian Kehutanan. Banjarbaru.

Haryono, 2011. Konsep dan Strategi Penelitian dan Pengembangan Pestisida Nabati. Kepala Badan Penelitian dan pengembangan Pertanian Kementerian Pertanian. Seminar Nasional Pesnab IV 15 Oktober 2011. Jakarta.

Laila Nur Milati dan Nunung Ambarwati. 2011. Resep-Resep Insektisida Botani Yang Efektif Untuk Berbagai Jenis Hama Tanaman Padi. Agroteknologi. Fakultas Pertanian. Universitas Sebelas Maret. Surakarta.

Muhammad Sarjan, 2008. Potensi Pemanfaatan Insektisida Nabati Dalam Pengendalian Hama Budidaya Sayuran Organik. Program Studi Hama dan Penyakit Tumbuhan, Fakultas Pertanian Universitas Mataram, Jl. Pendidikan Mataram, Lombok, Nusa Tenggara Barat.

Samsudin. 2014. Pengendalian Hama dengan Pestisida Nabati. Pertanian Sehat Indonesia. Bogor.

Tien Aminatun, dkk. 2013. Workshop Pembuatan Pestisida Nabati Yang Ramah Lingkungan Bagi Petani-Petani di Kecamatan Berbah kabupaten Sleman. Fakultas Matematika dan Ilmu Pengetahuan Alam, Universitas Negeri Jogjakarta 